\title{
The glomerular parietal epithelial cell's responses are influenced by SM22 alpha levels
}

Shokichi Naito ${ }^{1,2}$, Jeffrey W Pippin ${ }^{1}$ and Stuart J Shankland ${ }^{1 *}$

\begin{abstract}
Background: Studies have shown in several diseases initially affecting podocytes, that the neighboring glomerular parietal epithelial cells (PECS) are secondarily involved. The PEC response might be reparative under certain circumstances, yet injurious under others. The factors governing these are not well understood. We have shown that SM22a, an actin-binding protein considered a marker of smooth muscle differentiation, is upregulated in podocytes and PECs in several models of podocyte disease. However, the impact of SM22a levels on PECs is not known.

Methods: Experimental glomerular disease, characterized by primary podocyte injury, was induced in aged-matched SM22a +/+ and SM22a -/- mice by intraperitoneal injection of sheep anti-rabbit glomeruli antibody. Immunostaining methods were employed on days 7 and 14 of disease.

Results: The number of PEC transition cells, defined as cells co-expressing a PEC protein (PAX2) and podocyte protein (Synaptopodin) was higher in diseased SM22a -/- mice compared with SM22a +/+ mice. WT1 staining along Bowman's capsule is higher in diseased SM22a -/- mice. This was accompanied by increased PEC proliferation (measured by ki-67 staining), and an increase in immunostaining for the progenitor marker NCAM, in a subpopulation of PECs in diseased SM22a - /- mice. In addition, immunostaining for vimentin and alpha smooth muscle actin, markers of epithelial-tomesenchymal transition (EMT), was lower in diseased SM22a -/- mice compared to diseased SM22a+/+ mice.

Conclusion: SM22a levels may impact how PECS respond following a primary podocyte injury in experimental glomerular disease. Absent/lower levels favor an increase in PEC transition cells and PECs expressing a progenitor marker, and a lower EMT rate compared to SM22a +/+ mice, where SM22 levels are markedly increased in PECs.
\end{abstract}

Keywords: Regeneration, WT-1, Podocyte, Glomerulus, Progenitor

\section{Background}

Adult podocytes are terminally differentiated glomerular epithelial cells that are unable to proliferate adequately to replace those lost in glomerular diseases $[1,2]$. Reduced podocyte number leads to proteinuria and glomerulosclerosis in diabetic and non-diabetic glomerular diseases [2-7]. The interplay between the parietal epithelial cell (PECs) and visceral epithelial cell (podocyte) has been keenly studied recently in experimental and human glomerular diseases. Studies in humans, and in adolescent PEC reporter mice, support a paradigm where PECs function as local progenitors for podocytes [8-10]. In normal human and rodent glomeruli, a subset of PECs

\footnotetext{
*Correspondence: stuartjs@ u.washington.edu

'Division of Nephrology Department of Medicine, University of Washington School of Medicine, Box 356521, 1959 NE Pacific St., Seattle, WA 98195-6521, USA

Full list of author information is available at the end of the article
}

co-express proteins considered unique to both podocytes, and to PECs $[8,9,11-14]$. Some have called these transitional cells [8,11-14]. Moreover, a subset of PECs in humans and rodents express proteins considered as general markers for stem/progenitor cells, suggesting the possibility that a renal progenitor system exists [15]. Recent studies in mice have disputed this concept [16-19].

Two lines of evidence suggest that rather than PECs being regenerative, PECs augment glomerular damage following podocyte injury. First, their activation as evidenced by the de novo expression of CD44 likely contributes to disease progression by augmenting scarring and crescent formation under certain circumstances [20,21]. Second, in response to injury PECs can also undergo epithelial-tomesenchymal transition (EMT) [22-27], which is a phenotypic change characterized by loss/decrease of epithelial characteristics while attaining features of mesenchymal 
cells. Another view is that these different PEC "phenotypes" (i.e. progenitors, activated-CD44 positive, EMT) are not mutually exclusive.

The mechanisms associated with PEC EMT are not well defined. SM22 $\alpha$, also known as transgelin, is a $22-\mathrm{kDa}$ actin-binding protein of the calponin family, a cytoskeleton associated protein and one of the earliest markers of smooth muscle differentiation [28,29]. Although SM22 $\alpha$ is absent in normal glomeruli, it is markedly increased in diseased glomeruli, in both podocytes and PECs [30-32]. The kidneys of SM22 $\alpha$-deficient mice develop normally and appear similar to wildtype mice histologically [33]. However, we and others have shown that SM22 $\alpha$ staining is markedly increased in experimental animal models of membranous nephropathy (PHN model), FSGS (PAN, ADR nephropathy, obesity-related glomerulopathy), crescentic glomerulonephritis (anti-GBM nephritis model), mesangial proliferation (anti-Thy1 model) and obstructive nephropathy (UUO model) [27,30,31,34-39]. In these studies, de novo SM22 $\alpha$ expression was detected in podocytes, as well as in PECs. When experimental crescentic glomerulonephritis was induced, SM22 $\alpha+/+$ mice had more severe glomerular disease compared to SM22 $\alpha-/-$ mice, marked by greater podocyte apoptosis, lower podocyte number, more proliferation, and increased activation of Erk1/2 [32], indicating SM22 $\alpha$ likely plays a deleterious role in podocytes.

The focus of these earlier studies was on SM22 $\alpha$ and the podocyte [32,34-36]. Since then, interest in PECs has increased substantially, enhancing our understanding of this less well defined glomerular epithelial cell [21,22,40,41]. Accordingly, in the current experiments, we studied the potential biological affect of SM22 $\alpha$ on PECs in experimental glomerular disease, with a focus on glomerular epithelial transition cells and EMT.

\section{Methods \\ Passive nephrotoxic models of experimental crescentic glomerulonephritis}

SM-CreERT2(ki) transgenic mice were used, which have been extensively characterized previously [32]. We have also previously reported that giving these mice sheep antiglomerular antibody used in this study leads to passive nephrotoxic crescentic glomerulonephritis, with varying degrees of capillary loop dilatation, mesangial expansion, crescent formation with increased WT-1 and Ki-67 staining in the glomerular tuft [32,42]. Please not that this is not the same antibody used to induce an experimental model of classic FSGS, which we have reported is characterized by reduced podocyte number and an absence of glomerular epithelial cell proliferation $[11,13,14,43]$.

The passive nephrotoxic nephritis model was induced in male SM22 $\alpha$ wildtype $(+/+)$ and null $(-/-)$ mice, aged $12 \mathrm{wk}$, by intraperitoneal injection of sheep anti-rabbit glomeruli antibody [12. $5 \mathrm{mg} / 20 \mathrm{~g}$ body weight 2 doses at days 0 and 3]. These mice were randomly assigned into the following groups: day $0(\mathrm{n}=6+/+$ and $-/-$ mice), day $7(\mathrm{n}=10,+/+$ and $-/-$ mice $)$ and day $14(\mathrm{n}=$ $5+/+$ and $-/-$ mice). The sheep anti-rabbit glomeruli antibody was produced by immunizing sheep with whole rabbit glomeruli, as previously described [42]. Control animals did not receive the sheep anti-rabbit glomeruli antibody. The animal care committee of the University of Washington, School of Medicine reviewed and approved the experimental protocol and animal procedures were conducted following Institutional Animal Care and Use Committee review.

\section{Immunohistochemistry staining methods Identifying transition cells}

To identify and quantitate the number of glomerular epithelial cells that express both a podocyte and PEC proteins (called glomerular epithelial transition cells), double immunostaining was performed as follows. Indirect immunofluorescence was performed on 4 um-thick section kidney biopsies fixed in formalin and embedded in paraffin as we have previously reported [12-14,32,43]. In brief, paraffin was removed using Histoclear (National Diagnostics, Atlanta, Ga., USA), and sections were rehydrated in ethanol. Antigen retrieval was performed by boiling sections in the microwave in $1 \mathrm{mM}$ EDTA, $\mathrm{pH}$ 6.0. Nonspecific protein binding was blocked with background buster (Accurate Chemical \& Scientific, Westbury, NY, USA) and endogenous biotin activity was quenched with the Avidin/biotin blocking kit (Vector Laboratories, Burlingame, CA, USA). After the blocking steps described above, tissue sections were incubated overnight at $4^{\circ} \mathrm{C}$ with the primary antibodies. The following primary antibodies were used: rabbit anti-rat paired box gene 2 (PAX2, a PEC nuclear protein) polyclonal antibody diluted 1:500 (Zymed Laboratories, South San Francisco, Calif., USA) and mouse anti- Synaptopodin (Synpo, a podocyte protein) monoclonal antibody, diluted 1:10 (Fitzgerald). The appropriate biotinylated secondary antibody (Vector Laboratories) was applied followed by Streptavidin, AlexaFluor 594 conjugate and Alexa 488 conjugate.

\section{Identifying podocyte and potential PEC progenitors}

The rabbit anti-WT-1 polyclonal antibody (Santa Cruz Biotechnology, USA), and NCAM ( Millipore, MA, USA) were used to identify podocyte and potential PEC progenitors . Positive cells being a bluish-gray color were visualized with the Vector SG substrate kit (Vector).

\section{Identifying EMT}

Indirect immunoperoxidase immunostaining was performed for PAX2 as described above, in combination with vimentin (1:100 Santa Cruz, CA, USA) and alpha- 
smooth muscle actin ( $\alpha$-SMA, 1:400 Abcam, UK).). Omission of the primary antibody was used as a negative control. Vimentin and $\alpha$-SMA staining were visualized with the Vector SG substrate kit; positive cells are bluish-gray color (Vector). Blocking steps were performed following SG substrate color development. Because $\alpha$-SMA and PAX2 antibody were developed in rabbits, an anti-rabbit IgG antibody Fab fragment (Jackson ImmunoResearch, West Grove, PA, USA) was used to saturate all the binding sites created during the first set of staining. In addition, peroxidase activity derived from the first set of staining was also blocked using alkaline phosphatase/horseradish peroxidase block (SurModics, MN, USA). Next, a second set of staining was performed for PAX2. A rabbit-onrodent AP-polymer kit (Biocare Medical, CA, USA) was used for additional blocking and substitutive secondary antibody according to the manufacturer's protocol. Staining was visualized with the Warp Red chromogen kit, red color (Biocare Medical).

\section{Measuring proliferation}

To quantitate changes in PEC proliferation in SM22 $\alpha$ mice rabbit anti-Ki-67 monoclonal antibody (Thermo Fisher Scientific, Fremont, Calif., USA) were used to identify proliferating cells. Both of them were visualized with the Vector SG substrate kit, with positive cells being a bluish-gray color (Vector). For all stains, negative controls consisted of omitting the primary antibodies.

\section{Staining quantitation and statistical analysis}

Quantification of positively stained cells was performed on individual animals at each time point using a combination of bright-field and fluorescent microscopy as we have reported [12-14]. The mean number

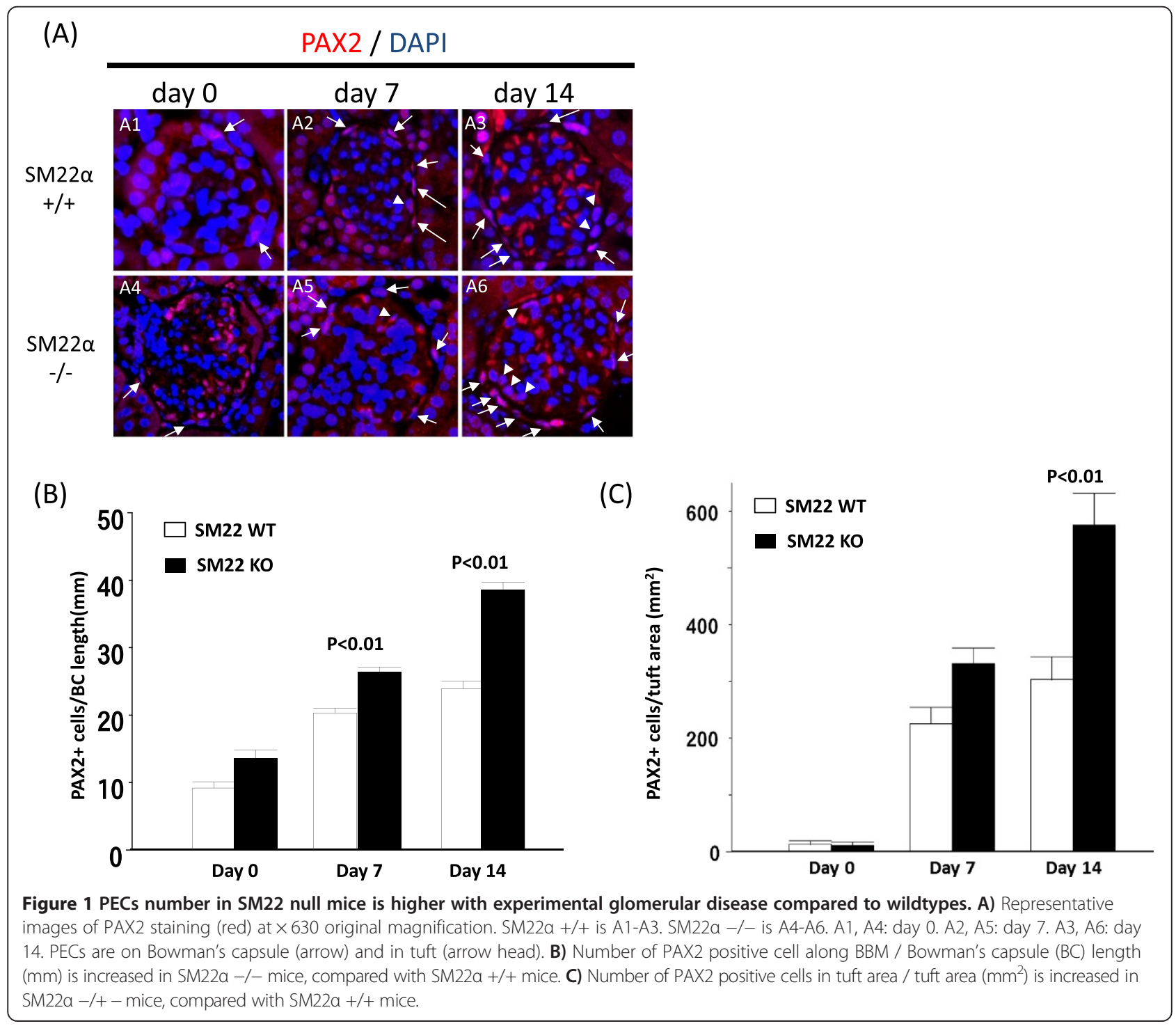


of glomeruli analyzed was 88 (95\% CI: 82-94) per animal. Because of known changes in glomerular size with aging and weight increasing, ImageJ software was used to measure the length of the Bowman's basement membrane and glomerular tuft area according to 'The ImageJ User Guide' (version 1.44) as we described previously [12-14]. These measures were then used as denominators for the number of positively stained podocytes, and double-stained cells along Bowman's capsule and in tuft, respectively.

Oneway ANOVA with unpaired t-test was calculated and a p-value below 0.05 was considered significant. The quantitative analyses of Bowman's capsule length and tuft area were evaluated by ImageJ. All values are means +/SEM. Statistical significance was evaluated using StatFlex version 6 (Artech Co., Ltd., Osaka, Japan).

\section{Results}

PEC number is higher in SM22 null mice with experimental glomerular disease compared to SM22 wildtype mice

To determine PEC number, PAX2 staining was performed and quantitated (Figure 1). Because of potential changes in glomerular size during disease, the length of Bowman's capsule, measured in millimeters, was used as the denominator. PEC number was expressed as the number of PAX2 positive cells/Bowman's capsule length in millimeters (Figure 1B). There was no statistical significance difference in PEC number at baseline between normal SM $22 \alpha+/+$ and SM $22 \alpha-/-$ mice $(9.19 \pm 0.93$ vs. $13.58 \pm 1.26$ PAX2 positive cells per mm of Bowman's capsule; $\mathrm{P}=0.08)$. However, in experimental glomerular disease, PEC number was higher than baseline, and SM22 $\alpha-/-$ mice had a higher number of PECs compared

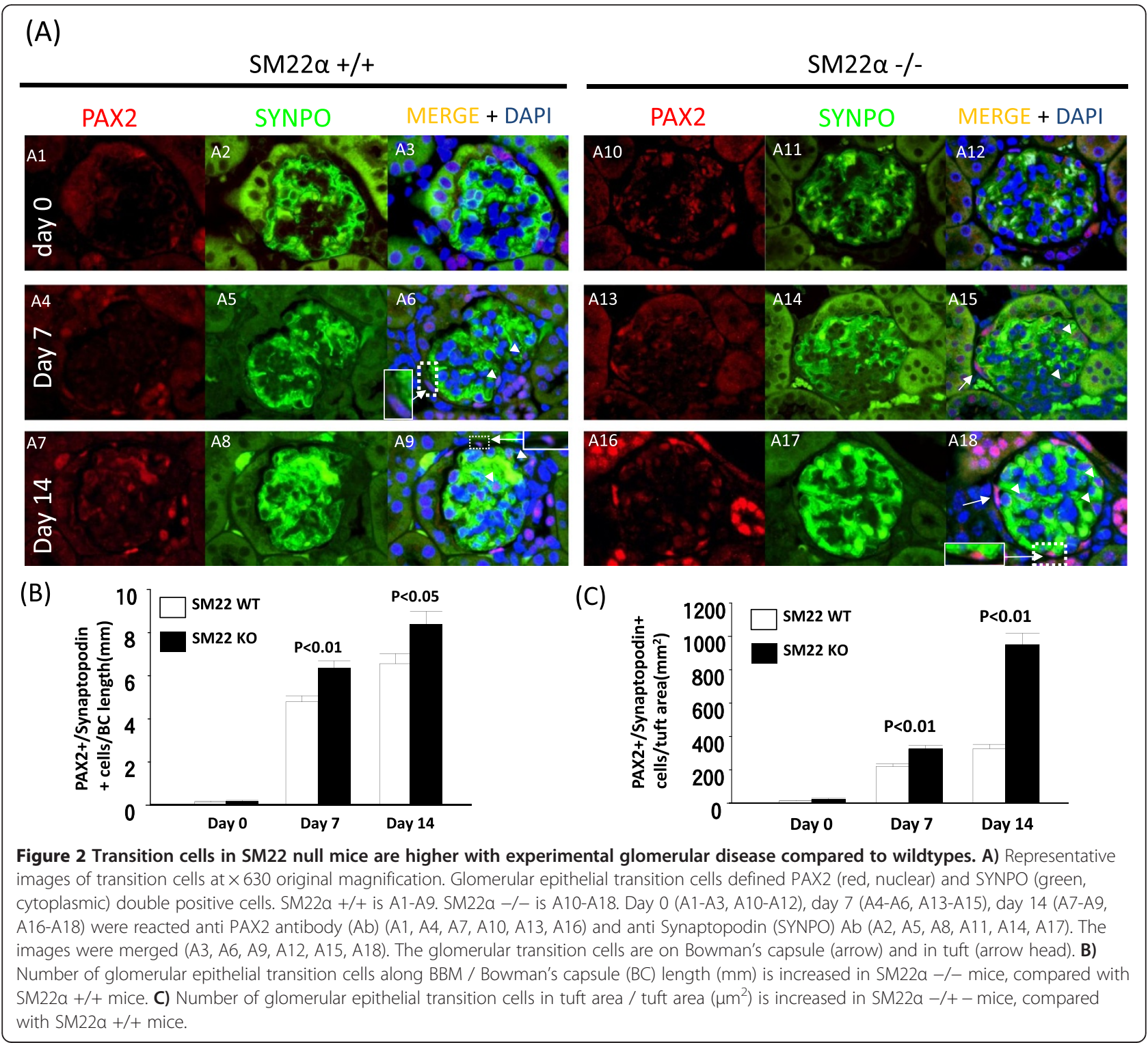




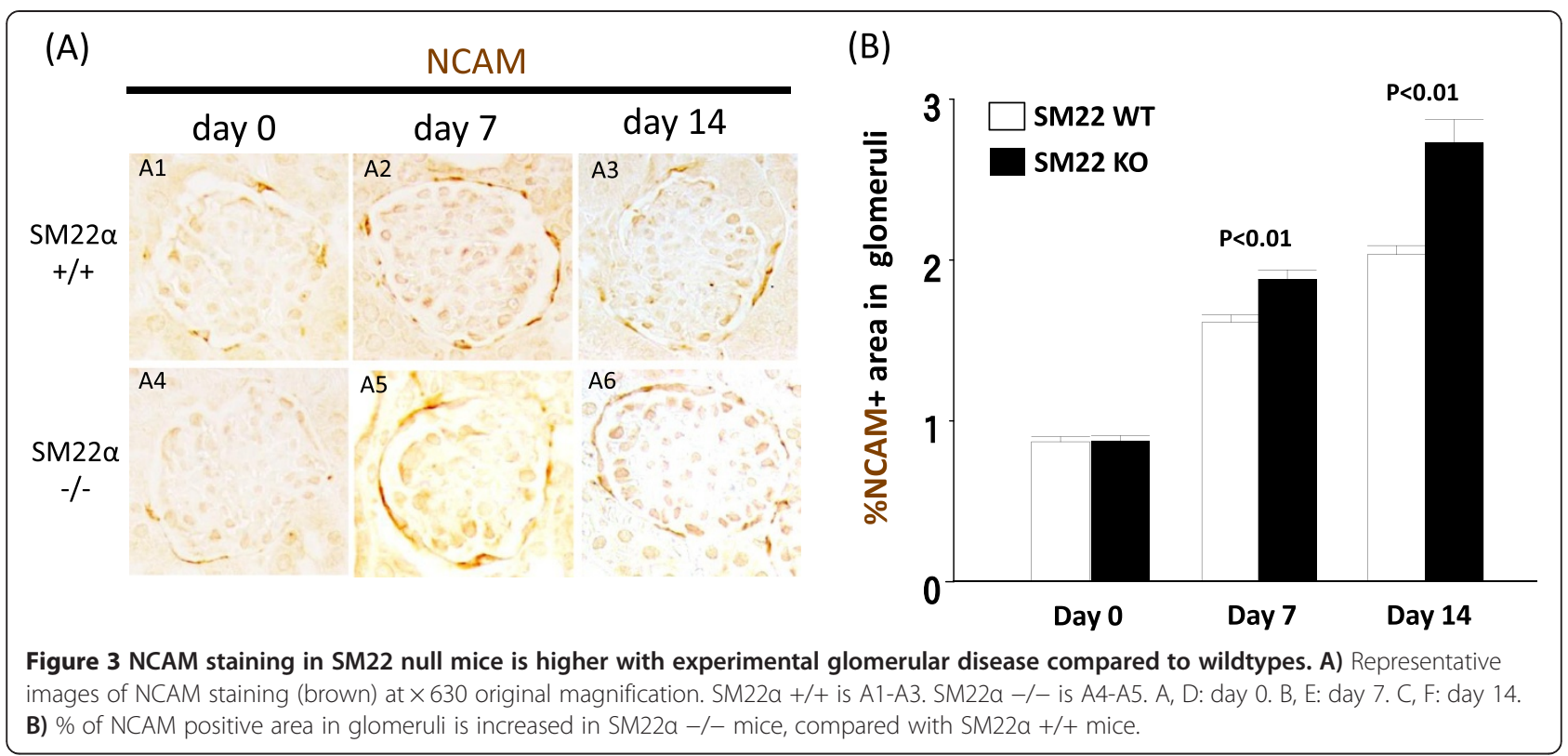

to SM22 $\alpha+/+$ mice at day $7(20.33 \pm 0.70$ vs. $26.38 \pm 0.73$ PAX2+ cells/Bowman's capsule length in mm, $\mathrm{P}<0.01$ ), and at day $14(23.92 \pm 1.14$ vs. $38.55 \pm 1.18 ; \mathrm{P}<0.01)$ (Figure 1B).

Because staining for PEC proteins have been detected in cells within the glomerular tuft, $[8,9,12-14]$, the number of PAX2 positive cells was also measured in the tuft, expressed per $\mathrm{mm}^{2}$ area. Very few PAX2 positive cells were in the tuft at baseline in SM22 $\alpha+/+$ and SM22 $\alpha-/-$ mice $\left(12.66 \pm 6.24 \mathrm{PAX} 2+\right.$ cells $/ \mathrm{mm}^{2}$ of glomerular tuft vs.10.08 \pm 6.60 ; $P=1.00$ ). However, in experimental glomerular disease, the number of PAX2 positive cells in the tuft increased, but was significantly higher in SM22 $\alpha-/-$ mice compared to SM22 $\alpha+/+$ mice at day $14(303.13 \pm$ 41.07 vs. $576.51 \pm 55.52$; $\mathrm{P}<0.01$ ) (Figure $1 \mathrm{C}$ ). The trend was also higher in SM22 -/- mice at day 7, but did not reach statistical significance $(225.27 \pm 29.00 v$ s. 331.59 \pm 27.79; $\mathrm{P}=0.126$ ).

Transition cells in SM22 null mice are higher with experimental glomerular disease compared to wildtypes Double immunofluorescent staining for PAX2 (PEC marker) and synaptopodin (podocyte marker) was performed to determine the number of glomerular

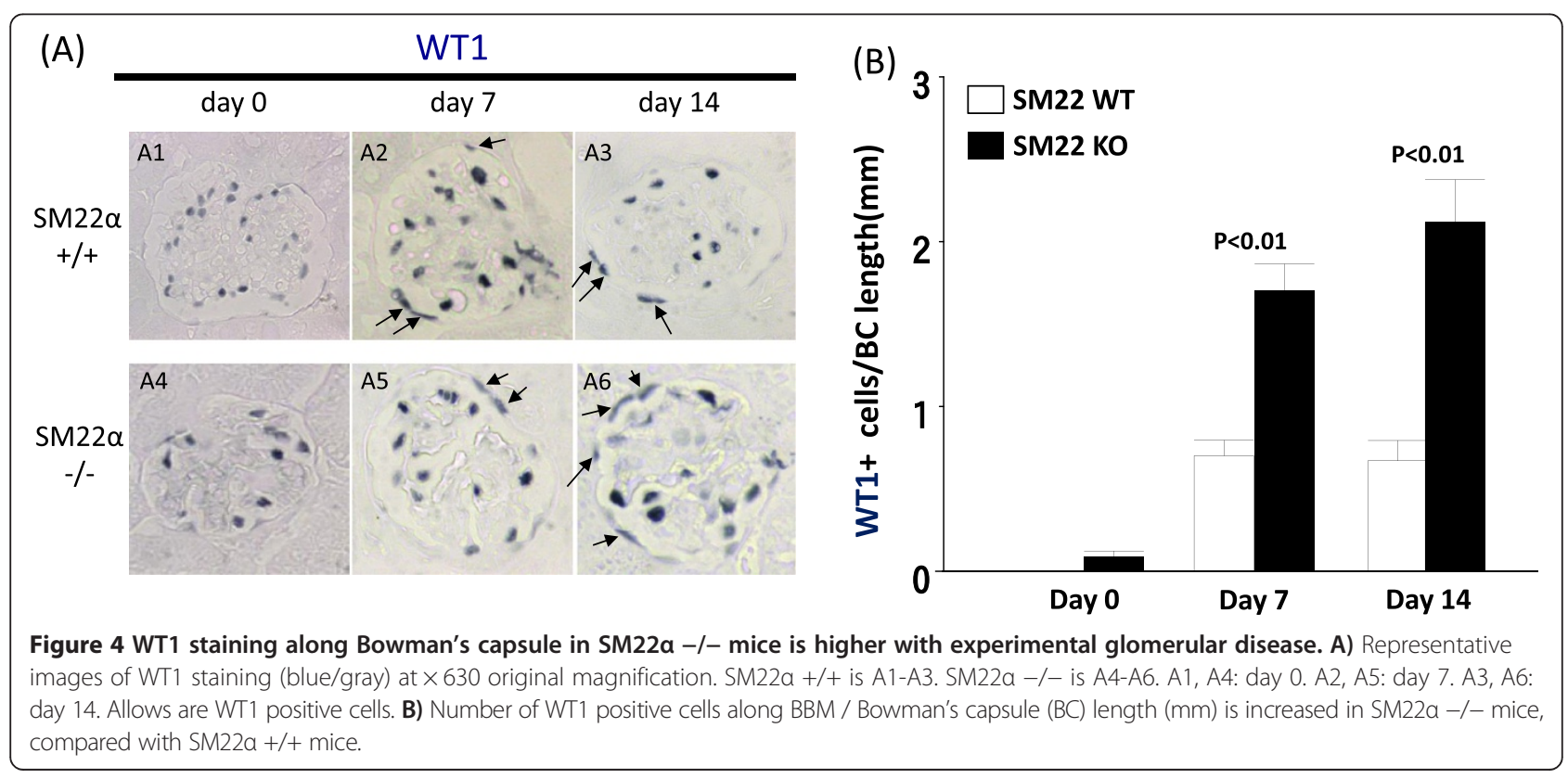


epithelial transition cells along Bowman's capsule, and within the glomerular tuft (Figure 2). At baseline, very few PAX $^{+} /$Synaptopodin $^{+}$cells were detected along Bowman's capsule in normal SM $22 \alpha+/+$ mice or $-/-$ mice $\left(0.15 \pm 0.04\right.$ vs. $0.18 \pm 0.05 \mathrm{PAX}^{+} /$Synaptopodin $^{+}$ cells/mm of Bowman's capsule, $\mathrm{P}=1.00$ ). The number of transition cells along Bowman's capsule increased significantly in both strains with experimental glomerular disease, although the magnitude of increase was greater in SM22 $\alpha-/-$ mice at day $7(6.35 \pm 0.34$ vs. $4.79 \pm 0.28$ $\mathrm{PAX}^{+} /$Synaptopodin $^{+}$cells $/ \mathrm{mm}$ of Bowman's capsule, $\mathrm{P}<0.01$ vs. $+/+)$, and day $14(8.38 \pm 0.60$ vs. $6.56 \pm 0.46$, $\mathrm{P}<0.05$ vs. $+/+$ ) (Figure $2 \mathrm{~B})$.

Transition cells that were barely detected in the glomerular tuft at baseline in SM22 $\alpha+/+$ or $-/-$ mice $\left(13.19 \pm 3.09\right.$, vs. $23.53 \pm 5.95 \mathrm{PAX}^{+} /$Synaptopodin $^{+}$cells/ $\mathrm{mm}^{2}$ of glomerular tuft; $\mathrm{P}=1.00$ ), increased in glomerular disease. The number of transition cells increased in SM22 $\alpha-/-$ mice with disease at day 7 (324.89 \pm 21.20 vs. $219.82 \pm 16.07, \mathrm{P}<0.01$ vs. $+/+)$, and at day $14(951.32 \pm$ 67.17 vs. $326.41 \pm 26.33, \mathrm{P}<0.01$ vs. $+/+$ ) (Figure $2 \mathrm{C}$ ).

These data show that the number of glomerular transition cells along Bowman's capsule and in the glomerular tuft was higher in diseased SM22 -/- mice compared to diseased SM22 +/+ mice.

NCAM staining in SM22 null mice is higher with experimental glomerular disease compared to wildtypes Neural cell adhesion molecule (NCAM) staining was used to identify potential PEC progenitors, similar to that described by Benigni (Figure 3A) [44]. At baseline, occasional NCAM staining was detected in cells lining Bowman's capsule in normal SM22 $\alpha+/+$ and $-/-$ mice $(0.87 \pm 0.03$ vs. $0.88 \pm 0.03 ; \mathrm{P}=1.00)$. NCAM staining increased in glomerular disease, but was higher in SM22 -/- mice at day $7(1.88 \pm 0.06$ vs. $1.61 \pm 0.05, \mathrm{P}<0.01$ vs. $+/+)$ and at day $14(2.73 \pm 0.14$ vs. $2.03 \pm 0.06, . \mathrm{P}<0.01$ vs. $+/+$ ) (Figure 3B). NCAM staining localized to PEC predominantly.

\section{WT1 staining along Bowman's capsule is higher in SM22} null mice with disease

WT-1 staining has traditionally been used as a marker to identify podocytes [45], WT-1 staining was barely detected along Bowman's capsule in SM22 $\alpha+/+$ and $-/-$ mice at baseline $(0.00 \pm 0.00$ vs. $0.09 \pm 0.04 ; \mathrm{P}=0.52)$ (Figure 4). However, in experimental glomerular disease, the number of WT-1 positive cells along Bowman's capsule was higher in SM22 $\alpha-/-$ mice at day 7 (1.70 \pm 0.16 vs. $0.70 \pm 0.09, \mathrm{P}<0.01$ vs. $+/+)$, and at day $14(2.12 \pm$ 0.26 vs. $0.67 \pm 0.12, P<0.01$ vs. $+/+$ ). Thus, similar to other studies $[9,11-14,40,46]$ WT-1 staining is increased in cells lining Bowman's capsule in mice with disease, and is higher SM22 -/- mice.

\section{Proliferation is higher in diseased SM22 null mice}

Ki-67 immunostaining, a proliferation marker [47], was barely detected along the Bowman's capsule at baseline in SM22 $\alpha+/+$ and $-/-$ mice $(0.07 \pm 0.04$ vs. $0.06 \pm 0.03$ positive cells/Bowman's capsule length; $\mathrm{P}=$ 1.00) (Figure 5A1 \& A4). Although the number increased in diseased SM22 $\alpha+/+$ mice, the number of Ki-67 cells along the Bowman's capsule was higher in diseased SM22 $\alpha-/-$ mice at day 7 (0.31 \pm 0.05 vs. $0.77 \pm$

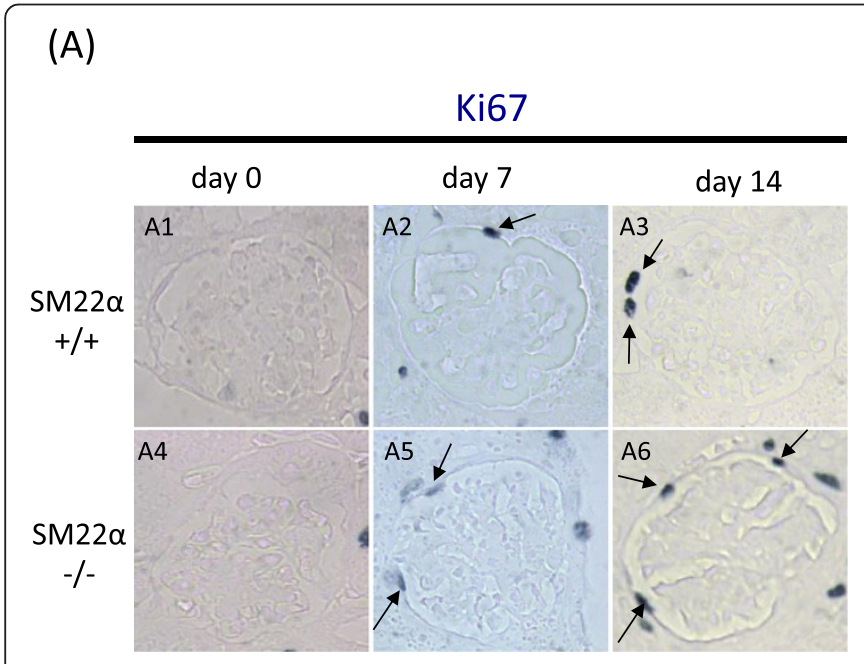

(B)

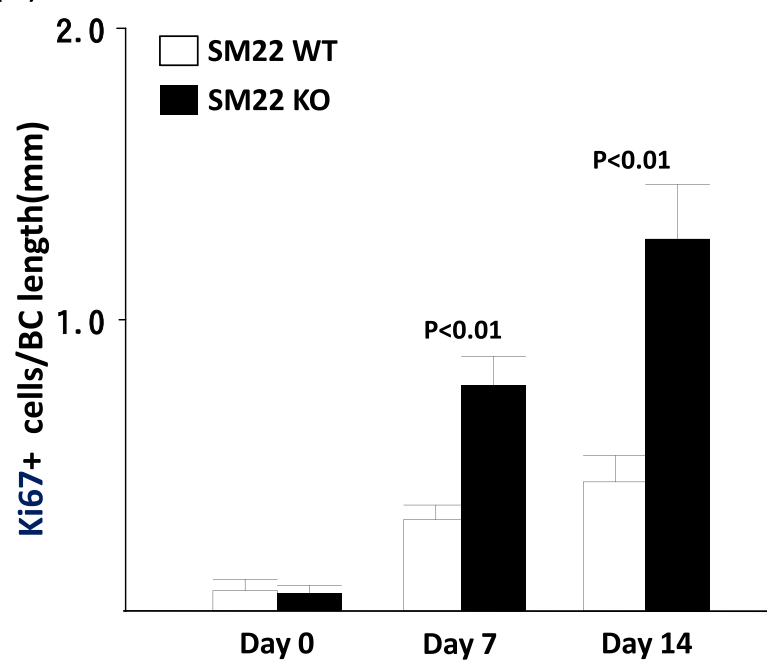

Figure 5 Proliferation is higher along Bowman's capsule in experimental glomerular disease in SM22 null mice. A)

Immunohistochemistry of Ki67 (blue/gray). SM22a +/+ is A1-A3. SM22a -/- is A4-A6. A1, A4: day 0. A2, A5: day 7. A3, A6: day 14. B) Number of Ki67 positive cells along BBM / Bowman's capsule (BC) length ( $\mathrm{mm}$ ) is increased in SM22a -/- mice, compared with SM22a +/+ mice. 
$0.10 ; \mathrm{P}<0.01)$, and at day $14(0.44 \pm 0.09$ vs. $1.28 \pm 0.19$; $\mathrm{P}<0.01$ ) (Figure 5A2, A3, A5, A6). These data show that a subset of cells along Bowman's capsule proliferate in disease, more so in SM22 $\alpha-/-$ mice than SM22 $\alpha+/+$ mice (Figure 5B).

Double staining for $\mathrm{Ki}-67$ and PAS was performed to evaluate proliferating cells in crescents (Figure 6A). In SM $22 \alpha+/+$ mice at day $7,15.36 \pm 1.46 \%$ of glomeruli contained crescents. SM22 $\alpha-/-$ mice with disease had fewer crescents at day $7(10.17 \pm 1.19 \%$ vs. $15.36 \pm 1.46 \%$; $\mathrm{P}<0.05$ vs. $+/+$ ) (Figure 6B). The percentage of crescents with Ki67+ demonstrate no significant difference between SM $22 \alpha+/+$ and SM $22 \alpha-/-$ mice at day $7(87.93 \pm 6.75 \%$ vs. $85.15 \pm 10.24 \%, \mathrm{P}=1.00)$, and at day $14(38.50 \pm 15.02 \%$ vs. $52.69 \pm 7.50 \%, \mathrm{P}=0.15)$. $\mathrm{Ki}-67$ staining was used as a marker of cell proliferation (Figure $6 \mathrm{C}$ ). Similar to the results shown above, the percentage of glomeruli with cells staining for Ki67 that were along Bowman's capsule but not within a crescent was higher in SM22 $\alpha-/-$ compared to SM $22 \alpha+/+$ at day $7(17.66 \pm 1.12$ vs. $14.65 \pm 0.43 ; \mathrm{P}=$ $0.32)$ and at day $14(22.1 \pm 1.00$ vs. $15.83 \pm 0.79, \mathrm{P}<0.05)$ (Figure 6D).

\section{Epithelial-to-mesenchymal transformation of PECs is}

lower in disease in SM22 null mice with experimental glomerular

Epithelial-to-mesenchymal transformation (EMT) has been reported in PECs in disease, and correlates with worse outcomes $[25,48]$. In order to determine if the levels of SM22 $\alpha$ affected PEC EMT, PAX2 (used as a PEC marker) was double-stained with classic EMT markers $\alpha$-smooth muscle actin ( $\alpha$-SMA) or vimentin (Figure 7 ). $\alpha-\mathrm{SMA}^{+} \mathrm{PAX}^{+}$double positive cells were very occasionally detected along Bowman's capsule in SM22 $\alpha+/+$ and SM $22 \alpha-/-$ mice at baseline $(0.03 \pm 0.02$ vs. $0.04 \pm 0.02$; $\mathrm{P}=1.00)$. At day 7 , the number of $\alpha-\mathrm{SMA}^{+} \mathrm{PAX} 2^{+}$double positive cells was higher in SM22 $+/+$ mice $(0.32 \pm 0.05$ vs. $0.10 \pm 0.03 ; \mathrm{P}=<0.01$ vs. $-/-)$. The number of $\alpha$-SMA

\section{(A) Ki67 with PAS staining}
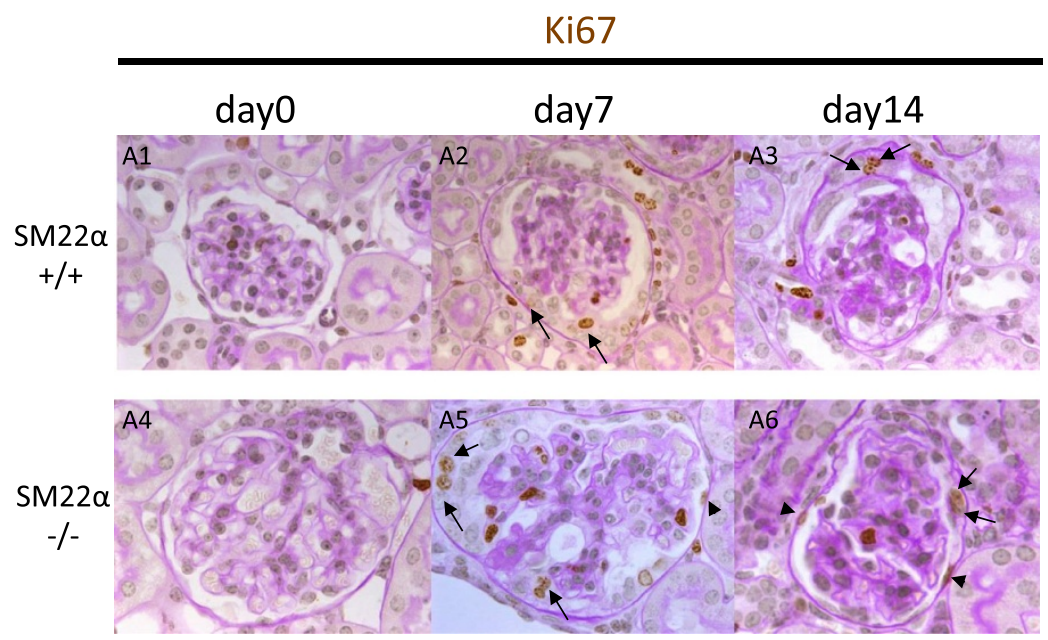

(B)

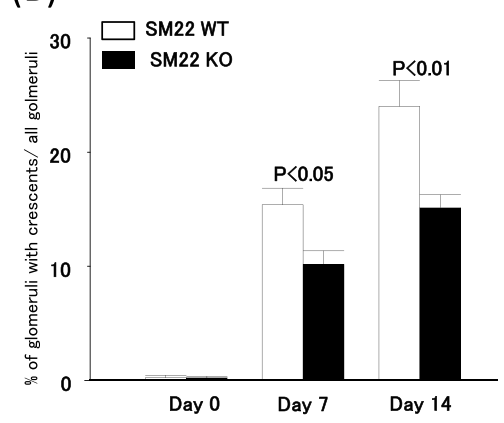

(C)

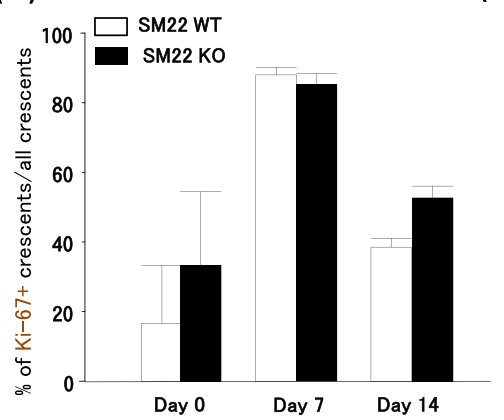

(D)

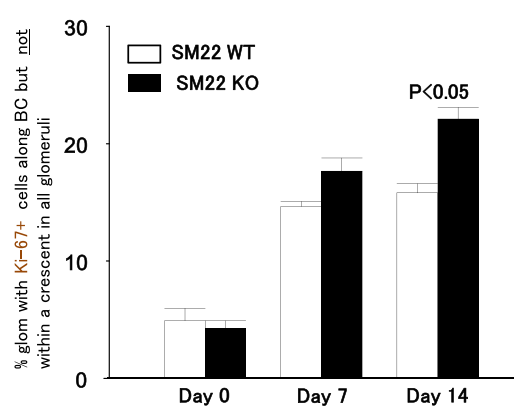

Figure 6 The crescent is higher in diseased SM22a +/+ mice. A) Representative images of Ki67 staining (blue/gray) at $\times 630$ original magnification. SM22a +/+ is A1-A3. SM22a -/- is A4-A6. A1, A4: day 0. A2, A5: day 7. A3, A6: day 14. Allows are Ki67+ cells in crescents. Allow heads are Ki67+ cells on Bowman's capsule (BC). B) \% glomeruli of crescent. C) \% crescent within Ki-67+ cells / all crescents. D) \% glomeruli with Ki67+ cells outside of crescents on Bowman's capsule (BC) / all glomeruli. 


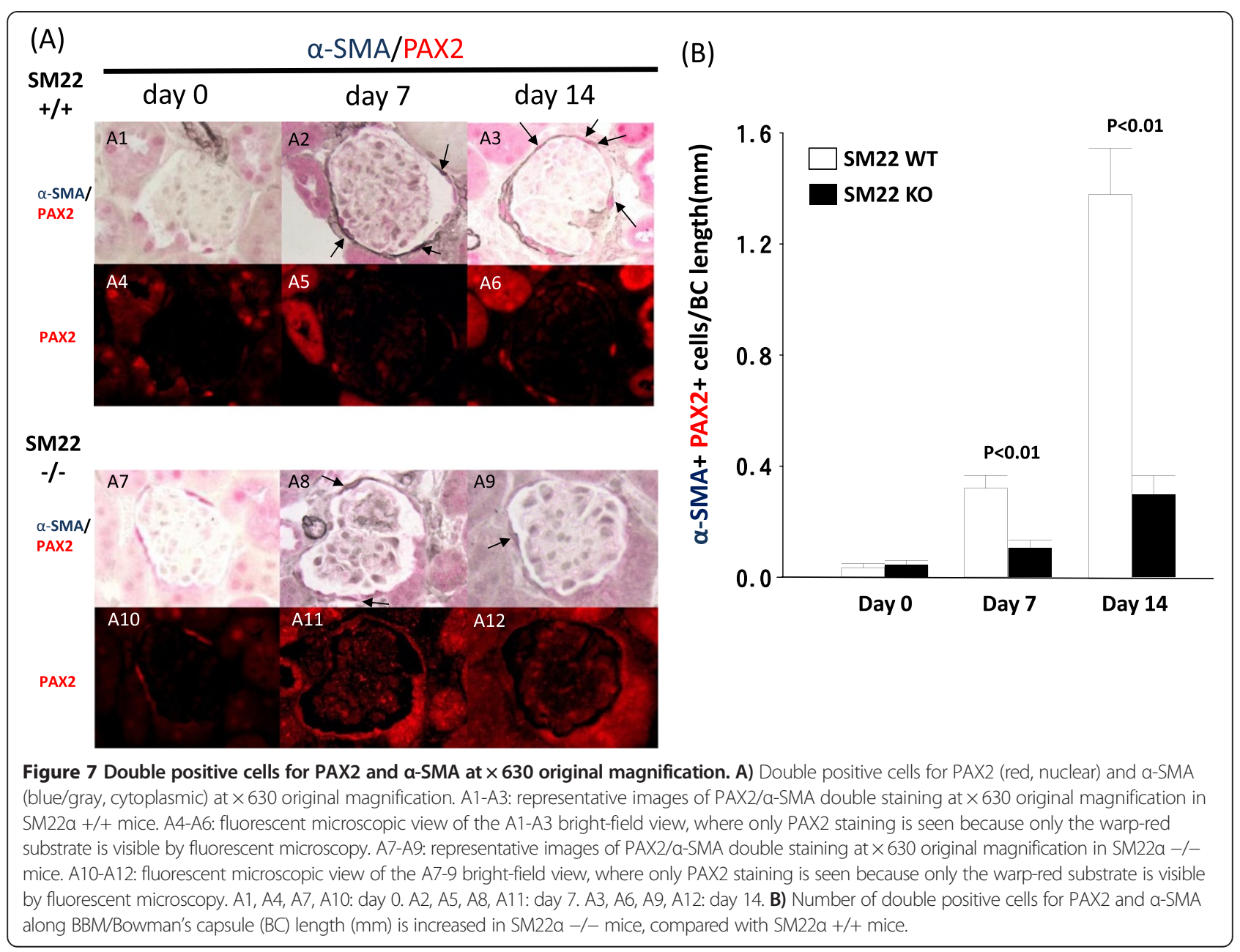

${ }^{+} \mathrm{PAX}^{+}$double positive cells was even higher at day 14 in SM22 $\alpha+/+$ mice compared to SM22 $\alpha-/-$ mice (1.38 \pm 0.17 vs. $0.30 \pm 0.07 ; \mathrm{P}<0.01$ vs. $-/-$ ) (Figure 7).

Double staining for vimentin and PAX2, was barely detected along Bowman's capsule at baseline in SM22 $\alpha+/+$ and $-/-$ mice $(0.03 \pm 0.02$ vs. $0.03 \pm 0.02 ; \mathrm{P}=1.00)$. The number of vimentin ${ }^{+} \mathrm{PAX} 2^{+}$double positive cells along the Bowman's capsule was higher in SM22 $\alpha+1+$ mice at day 7 $(2.10 \pm 0.20$ vs. $3.39 \pm 0.27 ; \mathrm{P}<0.01$ vs. $-/-)$ and day 14 $(2.38 \pm 0.32$ vs. $4.57 \pm 0.44 ; \mathrm{P}<0.01$ vs. $-/-)$ (Figure 8 ).

These data show that two markers of EMT are significantly higher in PECs in SM22 wildtype mice compared to null mice with disease.

\section{Discussion}

Studies in man show that PECs might play a critical role in glomerular repair through their progenitor function $[8,9,15,21]$. However, PECs might paradoxically contribute to the deterioration of glomerular function by augmenting scarring and crescent formation under certain circumstances in man and mouse [21]. The precise mechanisms underlying this dichotomy are poorly understood.
Because SM22 $\alpha$ was markedly increased in PECs (and podocytes) in diseases considered primarily podocyte in nature [27,30,31,34-39], the purpose of the current studies was to determine if the levels of SM22 had any affect on certain PEC properties in response to primary injury to podocytes.

The first major finding was that in experimental glomerular disease, there was a direct association between reduced SM22 levels and increased PEC number, including an increase in the PEC transition cell subpopulation. The latter was supported by a higher number of cells costaining for a PEC protein, and two podocyte proteins, namely synapotopodin and WT-1. Moreover, there is a subset of PECs along Bowman's capsule that have increased expression for NCAM. NCAM expression has been shown in metanephric mesenchyme and in the glomerular capsule in the mature kidney [49,50]. Others have shown that NCAM is a marker of renal progenitor cells $[44,51]$. This suggests, but does not prove, that the subpopulation of PECs that might acquire a progenitor phenotype in disease is higher in the absence of SM22. Given that studies have shown that reduced SM22 $\alpha$ 


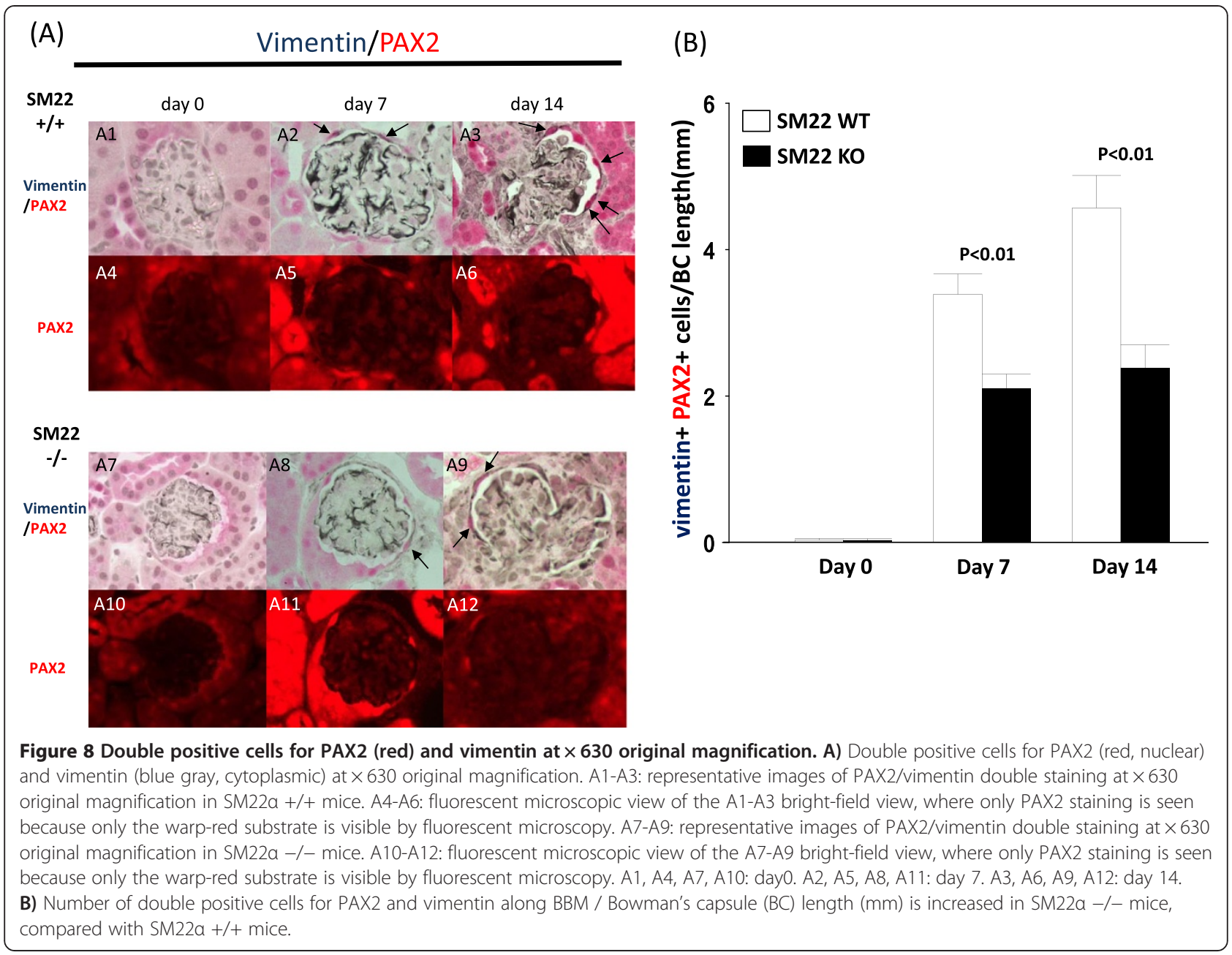

levels have a proliferative effect in vascular smooth muscle cells and prostate tumor cells [52,53], and that SM22 levels were significantly reduced in proliferating cells in prostate, lung, breast, gliobrastoma and colorectal cancers [54-56], it is perhaps not surprising that PECs had higher proliferation in mice deficient in SM22 $\alpha$.

A second major finding in the current study was that although epithelial-to-mesenchymal transition (EMT) occurred in both strains of mice with disease, the magnitude of EMT was higher in SM22+/+mice compared to SM22 - /- mice, judged by the EMT markers alpha smooth muscle actin and vimentin. EMT in kidney and non-kidney cell types has been associated with fibrosis, and is therefore considered undesirable [57]. Indeed, studies have previously demonstrated EMT in PECs. Studies by Yee-Yung [23] and Shimizu [58] showed that PEC EMT was deleterious. In contrast, Swetha showed that EMT plays a role in plasticity of cultured PECs [26], which is considered beneficial. In the current study our data supports a notion that PEC
EMT is significantly lower in mice lacking SM22 $\alpha$. One might the current data that the lower PEC EMT in null mice with disease is consistent with an overall improved outcome.

Several limitations to this manuscript are noted, although they do not substantially impact the enthusiasm for the findings. First, although mice with genetically altered SM22 level are used, this is largely descriptive. Second, an alternate explanation to both major findings is that they are independent from SM22 levels, because the podocyte lesion is worse in null mice. Regardless, this is informative, because the latter explanation would suggest that the degree of PEC response correlates with the degree of podocyte damage. One might even argue that the differences in the PEC responses are due to differences in the immune response to injury between the null and wildtype strains used. Please note that although the data was not shown, there were no differences between the two mouse strains in the amount of disease-inducing antibody deposited in podocytes (it does not deposit in PECs). We have previously 
reported that this model is not characterized by an inflammatory cell response, which makes this an unlikely contributor to underlie any differences between SM22 -/and $+/+$ mice.

\section{Conclusions}

PECs are increasingly being recognized as second responders following a primary injury to neighboring podocytes. On one hand, the secondary response by PECs might be reparative if they indeed are a source of podocyte progenitors. The data from the current study suggests that they do express a putative progenitor marker (NCAM), and that the number of transition cells is increased. These events are augmented in the absence of SM22 $\alpha$. On the other hand, the secondary response by PECs can be deleterious if they are activated to express CD44 or undergo EMT. Our data shows that PEC EMT is reduced in mice lacking SM22 $\alpha$. Taken together, the current data support a model that when PECs are unable to express (or increase) SM22 $\alpha$ in a model of podocyte injury, they tend to favor a less injurious response judged by enhanced progenitor markers and less EMT. Further studies are needed to better delineate these pathways and to provide functional proof of this concept.

\section{Abbreviations \\ PEC: Parietal epithelial cell; FSGS: Focal segmental glomerulosclerosis; EMT: Epithelial-to-mesenchymal transformation; a-SMA: Alpha-smooth muscle actin.}

\section{Competing interests}

The authors declare that they have no competing interests.

\section{Authors' contributions}

SS, JP, SN: study design, SN: collection and analysis of data, and drafting of the manuscript, SS: critical revision of the article for important intellectual content and final approval of the article. All authors read and approve the final manuscript.

\section{Acknowledgements}

Grant Numbers: Aspects of work were supported by R01DK056799 (SJS), R21DK081835 (SJS).

\section{Author details}

'Division of Nephrology Department of Medicine, University of Washington School of Medicine, Box 356521, 1959 NE Pacific St., Seattle, WA 98195-6521, USA. ²Department of Nephrology, Kitasato University School of Medicine, 1-15-1 Kitasato, Minami-ku, Sagamihara, Kanagawa 252-0329, Japan

Received: 6 August 2014 Accepted: 22 October 2014 Published: 6 November 2014

\section{References}

1. Marshall CB, Shankland SJ: Cell cycle regulatory proteins in podocyte health and disease. Nephron Exp Nephrol 2007, 106(2):e51-e59.

2. Shankland SJ: The podocyte's response to injury: role in proteinuria and glomerulosclerosis. Kidney Int 2006, 69(12):2131-2147.

3. Pagtalunan ME, Miller PL, Jumping-Eagle S, Nelson RG, Myers BD, Rennke HG, Coplon NS, Sun L, Meyer TW: Podocyte loss and progressive glomerular injury in type II diabetes. J Clin Invest 1997, 99(2):342-348.

4. Lerco MM, Macedo CS, Silva RJ, Pinheiro Dde O, Spadella CT: The number of podocyte and slit diaphragm is decreased in experimental diabetic nephropathy. Acta Cir Bras 2006, 21(2):87-91.
5. Wiggins RC: The spectrum of podocytopathies: a unifying view of glomerular diseases. Kidney Int 2007, 71(12):1205-1214.

6. Kim YH, Goyal M, Kurnit D, Wharram B, Wiggins J, Holzman L, Kershaw D, Wiggins R: Podocyte depletion and glomerulosclerosis have a direct relationship in the PAN-treated rat. Kidney Int 2001, 60(3):957-968.

7. Wharram BL, Goyal M, Wiggins JE, Sanden SK, Hussain S, Filipiak WE, Saunders TL, Dysko RC, Kohno K, Holzman LB, Wiggins RC: Podocyte depletion causes glomerulosclerosis: diphtheria toxin-induced podocyte depletion in rats expressing human diphtheria toxin receptor transgene. J Am Soc Nephrol 2005, 16(10):2941-2952.

8. Appel D, Kershaw DB, Smeets B, Yuan G, Fuss A, Frye B, Elger M, Kriz W, Floege J, Moeller MJ: Recruitment of podocytes from glomerular parietal epithelial cells. J Am Soc Nephrol 2009, 20(2):333-343.

9. Ronconi E, Sagrinati C, Angelotti ML, Lazzeri E, Mazzinghi B, Ballerini L, Parente E, Becherucci F, Gacci M, Carini M, Maggi E, Serio M, Vannelli GB, Lasagni L, Romagnani S, Romagnani P: Regeneration of glomerular podocytes by human renal progenitors. J Am Soc Nephro/ 2009, 20(2):322-332.

10. Sagrinati C, Netti GS, Mazzinghi B, Lazzeri E, Liotta F, Frosali F, Ronconi E, Meini C, Gacci M, Squecco R, Carini M, Gesualdo L, Francini F, Maggi E, Annunziato F, Lasagni L, Serio M, Romagnani S, Romagnani P: Isolation and characterization of multipotent progenitor cells from the Bowman's capsule of adult human kidneys. J Am Soc Nephrol 2006, 17(9):2443-2456.

11. Ohse T, Vaughan MR, Kopp JB, Krofft RD, Marshall CB, Chang AM, Hudkins KL, Alpers CE, Pippin JW, Shankland SJ: De novo expression of podocyte proteins in parietal epithelial cells during experimental glomerular disease. Am J Physiol Renal Physiol 2010, 298(3):F702-F711.

12. Zhang J, Hansen KM, Pippin JW, Chang AM, Taniguchi Y, Krofft RD, Pickering SG, Liu ZH, Abrass CK, Shankland SJ: De novo expression of podocyte proteins in parietal epithelial cells in experimental aging nephropathy. Am J Physiol Renal Physiol 2012, 302(5):F571-F580.

13. Zhang J, Pippin JW, Krofft RD, Naito S, Liu ZH, Shankland SJ: Podocyte repopulation by renal progenitor cells following glucocorticoids treatment in experimental FSGS. Am J Physiol Renal Physiol 2013, 304(11):F1375-F1389.

14. Zhang J, Pippin JW, Vaughan MR, Krofft RD, Taniguchi Y, Romagnani P, Nelson PJ, Liu ZH, Shankland SJ: Retinoids Augment the Expression of Podocyte Proteins by Glomerular Parietal Epithelial Cells in Experimental Glomerular Disease. Nephron Exp Nephrol 2012, 121(1):e23-e37.

15. Romagnani P, Remuzzi G: Renal progenitors in non-diabetic and diabetic nephropathies. Trends Endocrinol Metab 2013, 24(1):13-20.

16. Berger K, Schulte K, Boor P, Kuppe C, van Kuppevelt TH, Floege J, Smeets B, Moeller MJ: The Regenerative Potential of Parietal Epithelial Cells in Adult Mice. J Am Soc Nephrol 2014, 25(4):693-705.

17. Wanner N, Hartleben B, Herbach N, Goedel M, Stickel N, Zeiser R, Walz G, Moeller MJ, Grahammer F, Huber TB: Unraveling the Role of Podocyte Turnover in Glomerular Aging and Injury. J Am Soc Nephrol 2014, 25(4):707-716 [Epub ahead of print].

18. Schulte K, Berger K, Boor P, Jirak P, Gelman IH, Arkill KP, Neal CR, Kriz W, Floege J, Smeets B, Moeller MJ: Origin of parietal podocytes in atubular glomeruli mapped by lineage tracing. J Am Soc Nephrol 2014, 25(1):129-141.

19. Sakamoto K, Ueno T, Kobayashi N, Hara S, Takashima Y, Pastan I, Matsusaka $T$, Nagata M: The direction and role of phenotypic transition between podocytes and parietal epithelial cells in focal segmental glomerulosclerosis. Am J Physiol Renal Physiol 2014, 306(1):F98-F104.

20. Shankland SJ, Anders HJ, Romagnani P: Glomerular parietal epithelial cells in kidney physiology, pathology, and repair. Curr Opin Nephrol Hypertens 2013, 22(3):302-309.

21. Ohse T, Pippin JW, Chang AM, Krofft RD, Miner JH, Vaughan MR, Shankland SJ: The enigmatic parietal epithelial cell is finally getting noticed: a review. Kidney Int 2009, 76(12):1225-1238.

22. Bariety J, Hill GS, Mandet C, Irinopoulou T, Jacquot C, Meyrier A, Bruneval P: Glomerular epithelial-mesenchymal transdifferentiation in pauci-immune crescentic glomerulonephritis. Nephrol Dial Transplant 2003, 18(9):1777-1784.

23. Ng YY, Fan JM, Mu W, Nikolic-Paterson DJ, Yang WC, Huang TP, Atkins RC, Lan HY: Glomerular epithelial-myofibroblast transdifferentiation in the evolution of glomerular crescent formation. Nephrol Dial Transplant 1999, 14(12):2860-2872.

24. Fujigaki Y, Sun DF, Fujimoto T, Suzuki T, Goto T, Yonemura K, Morioka T, Yaoita E, Hishida A: Mechanisms and kinetics of Bowman's epithelial-myofibroblast transdifferentiation in the formation of glomerular crescents. Nephron 2002, 92(1):203-212. 
25. Yadav A, Vallabu S, Kumar D, Ding G, Charney DN, Chander PN, Singhal PC: HIVAN phenotype: consequence of epithelial mesenchymal transdifferentiation. Am J Physiol Renal Physiol 2010, 298(3):F734-F744.

26. Swetha G, Chandra V, Phadnis S, Bhonde R: Glomerular parietal epithelial cells of adult murine kidney undergo EMT to generate cells with traits of renal progenitors. J Cell Mol Med 2011, 15(2):396-413.

27. Sakamaki Y, Sakatsume M, Wang X, Inomata S, Yamamoto T, Gejyo F, Narita I, Inomata S, Yamamoto T, Gejyo F, Narita I: Injured kidney cells express SM22alpha (transgelin): Unique features distinct from alpha-smooth muscle actin (alphaSMA). Nephrology (Carlton) 2011, 16(2):211-218.

28. Nishida W, Kitami $Y$, Hiwada K: cDNA cloning and mRNA expression of calponin and SM22 in rat aorta smooth muscle cells. Gene 1993, 130(2):297-302.

29. Assinder SJ, Stanton JA, Prasad PD: Transgelin: an actin-binding protein and tumour suppressor. Int J Biochem Cell Biol 2009, 41(3):482-486.

30. Ogawa A, Sakatsume M, Wang X, Sakamaki Y, Tsubata Y, Alchi B, Kuroda T, Kawachi H, Narita I, Shimizu F, Gejyo F: SM22alpha: the novel phenotype marker of injured glomerular epithelial cells in anti-glomerular basement membrane nephritis. Nephron Exp Nephrol 2007, 106(3):e77-e87.

31. Wang X, Sakatsume M, Sakamaki Y, Inomata S, Yamamoto T, Narita I: Quantitative histological analysis of SM22alpha (transgelin) in an adriamycin-induced focal segmental glomerulosclerosis model. Nephron Exp Nephrol 2012, 120(1):e1-e11.

32. Marshall CB, Krofft RD, Blonski MJ, Kowalewska J, Logar CM, Pippin JW, Kim F, Feil R, Alpers CE, Shankland SJ: Role of smooth muscle protein SM22alpha in glomerular epithelial cell injury. Am J Physiol Renal Physiol 2011, 300(4):F1026-F1042.

33. Zhang JC, Kim S, Helmke BP, Yu WW, Du KL, Lu MM, Strobeck M, Yu Q, Parmacek MS: Analysis of SM22alpha-deficient mice reveals unanticipated insights into smooth muscle cell differentiation and function. Mol Cell Biol 2001, 21(4):1336-1344.

34. Hauser PV, Perco P, Muhlberger I, Mühlberger I, Pippin J, Blonski M, Mayer B, Alpers CE, Oberbauer R, Shankland SJ: Microarray and bioinformatics analysis of gene expression in experimental membranous nephropathy. Nephron Exp Nephrol 2009, 112(2):e43-e58.

35. Miao J, Fan Q, Cui Q, Zhang H, Chen L, Wang S, Guan N, Guan Y, Ding J: Newly identified cytoskeletal components are associated with dynamic changes of podocyte foot processes. Nephrol Dial Transplant 2009, 24(11):3297-3305.

36. Inomata S, Sakatsume M, Sakamaki Y, Wang X, Goto S, Yamamoto T, Gejyo F, Narita I: Expression of SM22alpha (transgelin) in glomerular and interstitial renal injury. Nephron Exp Nephrol 2011, 117(4):e104-e113.

37. Daniel C, Lüdke A, Wagner A, Todorov VT, Hohenstein B, Hugo C: Transgelin is a marker of repopulating mesangial cells after injury and promotes their proliferation and migration. Lab Invest 2012, 92(6):812-826.

38. Karagianni F, Prakoura N, Kaltsa G, Politis P, Arvaniti E, Kaltezioti V, Psarras S, Pagakis S, Katsimboulas M, Abed A, Chatziantoniou C, Charonis A: Transgelin Up-Regulation in Obstructive Nephropathy. PLoS One 2013, 8(6):e66887

39. Ichimura K, Kawashima Y, Nakamura T, Powell R, Hidoh Y, Terai S, Sakaida I, Kodera Y, Tsuji T, Ma JX, Sakai T, Matsumoto H, Obara T: Medaka fish, Oryzias latipes, as a model for human obesity-related glomerulopathy. Biochem Biophys Res Commun 2013, 431(4):712-717.

40. Smeets B, Moeller MJ: Parietal epithelial cells and podocytes in glomerular diseases. Semin Nephrol 2012, 32(4):357-367.

41. Romagnani P: Parietal epithelial cells: their role in health and disease. Contrib Nephrol 2011, 169:23-36.

42. Pippin JW, Brinkkoetter PT, Cormack-Aboud FC, Durvasula RV, Hauser PV, Kowalewska J, Krofft RD, Logar CM, Marshall CB, Ohse T, Shankland SJ: Inducible rodent models of acquired podocyte diseases. Am J Physiol Renal Physiol 2009, 296(2):F213-F229.

43. Pippin JW, Sparks MA, Glenn ST, Buitrago S, Coffman TM, Duffield JS, Gross KW, Shankland SJ: Cells of renin lineage are progenitors of podocytes and parietal epithelial cells in experimental glomerular disease. Am J Pathol 2013, 183(2):542-557.

44. Benigni A, Morigi M, Rizzo P, Gagliardini E, Rota C, Abbate M, Ghezzi S, Remuzzi A, Remuzzi G: Inhibiting angiotensin-converting enzyme promotes renal repair by limiting progenitor cell proliferation and restoring the glomerular architecture. Am J Pathol 2011, 179(2):628-638.

45. Mundlos S, Pelletier J, Darveau A, Bachmann M, Winterpacht A, Zabel B: Nuclear localization of the protein encoded by the Wilms' tumor gene WT1 in embryonic and adult tissues. Development 1993, 119(4):1329-1341.
46. Bariety J, Mandet C, Hill GS, Bruneval P: Parietal podocytes in normal human glomeruli. J Am Soc Nephrol 2006, 17(10):2770-2780.

47. Urruticoechea A, Smith IE, Dowsett M: Proliferation marker Ki-67 in early breast cancer. J Clin Oncol 2005, 23(28):7212-7220.

48. Zoja C, Garcia PB, Rota C, Conti S, Gagliardini E, Corna D, Zanchi C, Bigini P, Benigni A, Remuzzi G, Morigi M: Mesenchymal stem cell therapy promotes renal repair by limiting glomerular podocyte and progenitor cell dysfunction in adriamycin-induced nephropathy. Am J Physiol Renal Physiol 2012, 303(9):F1370-F1381.

49. Abbate $\mathrm{M}$, Brown D, Bonventre JV: Expression of NCAM recapitulates tubulogenic development in kidneys recovering from acute ischemia. Am J Physiol 1999, 277(3 Pt 2):F454-F463.

50. Bard JB, Gordon A, Sharp L, Sellers WI: Early nephron formation in the developing mouse kidney. J Anat 2001, 199(Pt 4):385-392.

51. Pode-Shakked N, Metsuyanim S, Rom-Gross E, Mor Y, Fridman E, Goldstein I, Amariglio N, Rechavi G, Keshet G, Dekel B: Developmental tumourigenesis: NCAM as a putative marker for the malignant renal stem/progenitor cell population. J Cell Mol Med 2009, 13(8B):1792-1808.

52. Dong LH, Wen JK, Liu G, McNutt MA, Miao SB, Gao R, Zheng B, Zhang H, Han M: Blockade of the Ras-extracellular signal-regulated kinase 1/2 pathway is involved in smooth muscle 22 alpha-mediated suppression of vascular smooth muscle cell proliferation and neointima hyperplasia. Arterioscler Thromb Vasc Biol 2010, 30(4):683-691.

53. Yang Z, Chang YJ, Miyamoto H, Ni J, Niu Y, Chen Z, Chen YL, Yao JL, di Sant'Agnese PA, Chang C: Transgelin functions as a suppressor via inhibition of ARA54-enhanced androgen receptor transactivation and prostate cancer cell growth. Mol Endocrinol 2007, 21(2):343-358.

54. Yeo M, Park HJ, Kim DK, Kim YB, Cheong JY, Lee KJ, Cho SW: Loss of SM22 is a characteristic signature of colon carcinogenesis and its restoration suppresses colon tumorigenicity in vivo and in vitro. Cancer 2010, 116(11):2581-2589.

55. Gunnersen JM, Spirkoska V, Smith PE, Danks RA, Tan SS: Growth and migration markers of rat $\mathrm{C} 6$ glioma cells identified by serial analysis of gene expression. Glia 2000, 32(2):146-154.

56. Pang J, Liu WP, Liu XP, Li LY, Fang YQ, Sun QP, Liu SJ, Li MT, Su ZL, Gao X Profiling protein markers associated with lymph node metastasis in prostate cancer by DIGE-based proteomics analysis. J Proteome Res 2010, 9(1):216-226.

57. Mani SA, Guo W, Liao MJ, Eaton EN, Ayyanan A, Zhou AY, Brooks M, Reinhard F, Zhang CC, Shipitsin M, Campbell LL, Polyak K, Brisken C, Yang J, Weinberg RA: The epithelial-mesenchymal transition generates cells with properties of stem cells. Cell 2008, 133(4):704-715.

58. Shimizu M, Kondo S, Urushihara M, Takamatsu M, Kanemoto K, Nagata M, Kagami S: Role of integrin-linked kinase in epithelial-mesenchymal transition in crescent formation of experimental glomerulonephritis. Nephrol Dial Transplant 2006, 21(9):2380-2390.

\section{doi:10.1186/1471-2369-15-174}

Cite this article as: Naito et al:: The glomerular parietal epithelial cell's responses are influenced by SM22 alpha levels. BMC Nephrology 2014 15:174

\section{Submit your next manuscript to BioMed Central and take full advantage of:}

- Convenient online submission

- Thorough peer review

- No space constraints or color figure charges

- Immediate publication on acceptance

- Inclusion in PubMed, CAS, Scopus and Google Scholar

- Research which is freely available for redistribution 